\section{Cholera in Europe}

AN editorial in the Lancet of September 23, 1837, gives the following account of a pandernic of cholera at that time: "The cholera - that terrible epidemic, which after having exercised its ravages in all parts of the old and new world, seemed on the point of returning to the country which gave it birth, has again appeared raging with unabated violence not only in many of the southern States of Europe, but in some of the northern kingdoms, already more than once visited by the pestilence. Our readers are doubtless aware that the Asiatic cholera has been stalking along the Mediterranean shores of Europe for the last two or three years, and that, at the time we write, it has reached the capital of the Papal dominions. The progress of the disease through countries, the inhabitants of which are forcibly kept by their rulers in a state of ignorance, has been almost universally accompanied by disorder of the most serious nature.

"At Palermo the Governor has fallen a victim to the fury of a terrified and excited populace; and at Rome, if we are to believe the reports which have just reached us, the medical men are everywhere compelled to conceal themselves in order to avoid sharing the fate of several of their brethren, who are massacred during the period of excitement and consternation, which are produced at the onset of the malady. Marseille also has been attacked, for the third time, by the epidemic, which during several days carried off nearly 100 persons daily, and we are sorry to announce that the disease is spreading rapidly throughout the department of which that city forms the capital".

\section{Societies and Academies}

\section{Paris}

Academy of Sciences, July 5 (C.R., 205, 1-96).

Wolfgang Desblin : The elements of a general theory of the simple constant chains of Markoff.

Kentaro Yano: Totally geodesic non-holonome spaces.

MARCEL BRELOT : The best harmonic majorant of a sub-harmonic function.

RAPHAËL SALEM : A method of summation nearly always valid for Fourier's series of continuous functions.

Natan Aronszajn: A theorem of the theory of analytical functions of several complex variables.

JEAN LERAY and LouIs RoBIN : Complement to the study of the movement of an unlimited viscous liquid.

Pierre Vernotxe: Navier's equations and the dissipation function, in a hydraulic system. The thermal phenomena produced in the fluid by a rapid movement.

Max Teissie Solier, Luis Castagnetto and Marcel Sabathe : The beats which accompany the formation of the alternate vortices of Bénard Karmann.

André Lichnerowicz: Extension of the Gauss. Whittaker theorem.

Fritz London: The quantum theory of the diamagnetism of aromatic compounds.

TH. De Donder and J. GÉHÉNIAU : The electronic model of Dirac's wave mechanics.

JEAN JAFFRAY : Observation of the stratified Geissler discharge in different gases at atmospheric pressure. Under certain conditions, described in detail, stratification can be seen and photographed in Geissler tubes containing various gases at nearly atmospheric pressure.

Frantz PERrier : The action of an electric field on an electrified insulator placed in air : the ionization of the latter.

Alexandre Dauvillier : A universal counter. A modification of the Geiger-Müller counter, utilizing Richter and Geffcken relays with Neher and Harper mounting. The working voltage can be reduced to 300 volts, and the arrangement is suitable for measuring the intensity of the cosmic rays with captive balloons.

Georges AHIER : Christiansen filters. These filters are cells containing a transparent powder mixed with a liquid of the same refractive index. Study of the results obtained by varying the solid (flint and crown glass, fused silica, fluorspar) and the liquid.

Casimir Jausseran, líon Grillet and Michel. Duffieux : The fine structure of the 5998.9 band of nitric oxide.

Bertrand Goldschmydt : Study of the fractionation coefficients of salts possessing several hydrates. Study of the crystallization of barium acetate, with actinium $\mathrm{X}$ as indicator, and of strontium nitrate in presence of a trace of lead nitrate, with thorium $B$ as indicator.

Jean Perreu : The equation of solubility of a pure substance forming a solid compound with the solvent. Control of a differential equation obtained theoretically by an experimental study of the system sodium iodide and acetone.

Martial Félix Taboury and Marcel Bellot : The action of light on the Liesegang phenomenon.

Haldun N. Terem: The oxidation of beryllium bronzes.

Eugine Cattelain and Pierre Chabrier : Contribution to the separation of the phosphoric ion and its estimation by a volumetric method.

Jean Baron and Paul Laffitere: The inflammation of acetaldehyde. Determinations of the temperatures of spontaneous inflammation of various ternary mixtures of acetaldehyde and oxygen with nitrogen, argon or carbon dioxide as diluent.

Marc Trefeneau, Paul Weml and Bianca Tchoubar : The isomerization of eyclohexane methylene oxide into hexahydrobenzaldehyde, and the conversion of the corresponding amino-alcohol into cycloheptanone.

Marcel Sommelet : A particular mode of intramolecular rearrangement. Study of the decomposition by heat of $\left(\mathrm{C}_{6} \mathrm{H}_{5}\right)_{2} \mathrm{CH}-\mathrm{N}\left(\mathrm{CH}_{3}\right)_{3} \mathrm{OH}$.

WERNER LIPSCHITZ and ERNST BÜDING: The $d$ and $l$-borneolglucosides.

Panos Grammaticakis : Some modes of hydrolysis of the substituted $\mathrm{N}$-benzaldoximes.

JEAN KANDEL : The hydrocarbons, halogen derivatives, ethers and esters corresponding to tetrahydroionol.

JosepH Hoch : Contribution to the study of substances with female hormone properties. The synthesis of 2-oxo-6,7,8,9-tetrahydro-4,5-benzoacenaphthene.

Andrif Guillemonat : The oxidation by selenious oxide of cyclohexene and of the 3 and 4 nonenes.

RAYMOND Hocart: The structural scheme of proustite and pyrargyrite.

ANDRÉ VATAN: The comparative mineralogy of the sandy sediments of the Paris basin.

J. Gourc and Franck Bourdier : Pollen analysis and stratigraphical position of the Quaternary lignites of the Chambéry region. 
Théodore Monod: The geological constitution of the Mauritanian Adrar.

Alexandre Guillerd and Pierre Etrillard : The persistance of fluorescin in the soil. The influence of ferruginous formations.

Nrcolas Stoyko: The periodicity in the irregularity of the rotation of the earth.

Arthur Brunel and Robert Echevin: The evolution of nitrogen, appearance of allantoinase and of urease in the germination of rust (Agrostemma Githago).

JOSEPH LEFèvRE: The reversal of polarity produced in cuttings of Salix.

A. Guieysse-Pellissier : The presence of striated muscular fibre in the pulmonary arteries of the rat and the mouse.

Maurice Villaret, Henti Bénard, Louis Justin Besancon and Mlle Andrée Abadi: The mathematical study of the kinetics of hæmolysis (kinelysis).

LÉon KÉPINov : The antiglycogenolytic action of insulin.

RenÉ Salgues: Nutrient leucocytosis in reptiles in bad conditions of captivity.

JEAN LoISELEUR : The adsorption of polypeptides by proteins. The behaviour of a solution of peptone.

\section{Forthcoming Event}

Faraday Society, September 13-15.-General discussion on "Reaction Kinetics" to be held in the University of Manchester.

\section{Appointments Vacant}

APPLICATrONS are invited for the following appointments, on or before the dates mentioned:

ASSISTANT LECTURER AND A DFMONSTRATOR IN ELECTRICAL ENGINEERING in the Imperial College of Science and Technology (City and Guilds College), Prince Consort Road, S.W.7-Secretary (September 13).

Assistant Lecturer in Electrical ENgineering in the Manchester Municipal College of Technology-The Registrar (September 20).

Lecturer in Physical Chemistry (Grade II) in the University of Bristol-Secretary and Registrar (September 24).

SoIL CHEmist for the Rubber Research Scheme, Agalawatta, Ceylon-The Chairman (November 15).

INSPECTORS OF MINES in the Colonial Mines Service-The Director of Recruitment (Colonial Service), 2 Richmond Terrace, Whitehall, S.W.1.

\section{Official Publications Received}

\section{Great Britain and Ireland}

Forestry Commission. Special Leaflet No. 1: Pit-Props. Pp. 8. (London : Forestry Commission.)

Iron and Steel Institute. Special Report No. 18: Reports upon Blast-Furnace Field Tests. 1: An Investigation of a Blast-Furnace smelting principally Lincolnshire Ores at the Frodingham Works of the Appleby-Frodingham Steel Co. Ltd. Pp. v +98 . 10s. Special Report No. 19: Foamed Blast-Furnace Slag. By Dr. T. W. Parker. Forestry Commission. Bulletin No, 14: Forestry Practice; a Summary of Methods of Establishing Forest Nurseries and Plantations with Advice on other Forestry Questions for Owners and Agents. Revised edition. Pp. 99. (London: H.M. Stationery Office.) 1s. $6 d$. Revised edition. Pp. 99. (London: H.M. Stationery Office.) 1s. $6 d$.
net. The Journal of the Institute of Metals. Vol. 60. Edited by G. Shaw Scott. Pp. $456+59$ plates. (London: Institute of Metals.) [238 Air Ministry : Meteorological Office. Southport Auxiliary Observatory (the Fernley Observatory of the Corporation of Southport). Annual Report, and Result; of Meteorological Observations, for the Year 1936. By Alfred Goodwill. Pp. 32. (Southport: Fernley observatory ; London: Air Ministry.)
Air Ministry: Aeronautical Research Committee : Reports and Memoranda. No. 1760 (2458 and 2459): Progress of Experiments in Aero-Engine Exhaust Silencing. By A. W. Morley. Pp. 18. 28. 6d. net. No. 1761 (2362): The Stress in Certain Tubes of Rectangular Cross Section under Torque. By D. Williams. Pp. 34. 4s. 6d. net. No. $1766(2607)$ : Experiments on a Sphere at Critical Reynolds Numbers. By A. Fage. Pp. 20. 3s. net. No. $1771(2722)$ : Tests of Four Airscrew Sections in the Compressed Air Tunnel. By D. H Williams, A. F. Brown and E. Smyth. Pp. 20. 3s, net. No. 1774 (2675): Aerodynamic Characteristics of Tapered Wings with Flaps and Slots. By Dr. S. H. Hollingdale. Pp. 43. 6s. net. No. $1779(2693)$ Experiments on the Use of a Static Tube in the Wing Wake and Sxpert Pitot Tube in the Leading Edge as an Airspeed Indicator. B Short Pitot Tube in the Leading Edge as an Airspeed Indicator. By
the Aerodynamics Staff, R.A.E. Pp. 6. 1s. net. (London: H.M.

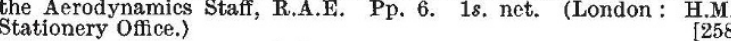
Other Countries

Government Museum, Trivandrum. Administration Report for the Year 1111 M.E. Pp. 8. A concise Guide for Visitors. Pp. 8

U.S. Treasury Department: Coast Guard. Bulletin No. 19: The Marion and General Green Expeditions to Davis Strait and Labrado Sea under direction of the United States Coast Guard 1928-1931-19331934-1935. Scientiflc Results, Part 2: Physical Oceanography. Pp. vi +259 . (Washington, D.C.: Government Printing Office.) 75 cents.

Report of the Kodaikanal Observatory for the Ycar 1936. Pp. 4 (Delhi: Manager of Publications.) 3 annas; $4 d$. Madras Fisheries Department. Administration Report for the Year 1935-36. By Dr. B. Sundara Raj. Pp. iii $+68+3$. (Madras: Government Press.) 8 annas.

Meteorological Office. Note No, 17 : Climatic Notes-New Zealand Districts. By Dr. E. Kídson. Pp. 32. (Wellington: Government

Statens Meteorologisl-Hydrografiska Anstalt Tillgör A 1936. Arsberättelse för 1936 Pr. 19 Arsbok 18 soversikt over våderlek och vattentillgang. Pp. $76.2 .50 \mathrm{kr}$. (11s.) Nederbörden i Sverige. Pp. 15. 2.50 kr. (Stockholm: Staten
Meteorologisk-Hydeograflska Anstalt.) Anales del Museo Argentino de Ciencias naturales. Antropologia, Etnologia y Arquelogia, Publicación No. 78: Fuéguidos y Láguidos, posición actual de la raza Paleo-americana o de Lagoa Santa. Por J. Imbelloni. Pp. 79-104. Publicación No. 79: Deformación del cráneo en la región de los Atacamenos y Diaguitas. Por el Prof. Ricardo E. Latcham. Pp. 105-124. (Buenos Aires: Museo Argentino
de Ciencias naturales.)
[238

Report Of the Botanical Survey of India for $1935-36$.
Calcutta: Government of India Press.)

Commonwealth of Australia: Council for Scientiflc and Industrial Research. Bulletin No. 105: Investigations on the Associated Growth of Herbage Plants. By H. C. Trumble, T. H. Strong and R. E. Shapter Pp. $40+10$ plates. Bulletin No. 106: Investigations on "Spotted Pp. $40+10$ plates. Bulletin No. 106: Investigations on "Spotted Pp. 32. (Melbourne: : Government Printer.)
[238 U.S. Department of the Interior: Office of Education. Bulletin, 1937, No. 2: Trends in Secondary Eiducation. Pp. vi +44.10 cents Pamphlet No. 71 : An Annotated Bibliography on the Education and Psychology of Exceptional Children. Prepared by Elise H. Martens and Florence E. Reynolds. Pp. iii +42 . 10 cents. (Washington, D.C. :
Government Printing Office.)

Classifled List of Smithsonian Publications available for Distribution, August 10, 1937. (Publication 3394.) Pp. vi + 35. (Washington, D.C. Smithsonian Institution.)

Smithsonian Miscellaneous Collections. Vol. 96, No. 1: Archeology of St. Lawrence Island, Alaska. By Henry B. Collins, Jr. (Publication 3411). Pp. xi $+431+84$ plates. (Washington, D.C.: Smithsonian
Institution.)

Proceedings of the United States National Museum. Vol. 84, No. 3017: Revision of the North American Species of Ichneumon-Flies of the Genus Exetastes Gravenhorst. By R. A. Cushman. Pp, 243-312+ plates 16-21. Vol. 84, No. 3018: A Revision of the Clapper Rails (Rallus longirostris Boddaert). By Harry C. Oberholser. Pp. 313-354. Vol. 84, No. 3019: Moths of the Genus Rupela (Pyralididæ: Schoenobiinæ). By Carl Heinrich. Pp. 355-388 + plates 22-33. (Washington, D.C.: Government Printing office.) Nyasaland Protectorate. Annual Report of the Forestry Department for the Year ended 31st December 1936. Pp. 18. (Zomba:
Government Printer.)

Publikationer fra det Danske Meteorologiska Institut. Communications magnétiques, etc., No. 18: Contribution à la connaissance de l'effet magnétique de l'électriflcation des chemins de fer. Par Dr. Mauritius Institute Bulletin. Vol. 1, Part 2: Revised Catalogue of the Testaceous Mollusca of Mauritius and its Dependencies. By R. Viader. Pp. xiii +111 . (Port Louis: Government Printer.) [238 Bernice P. Bishop Museum. Bulletin 143: Revision of the Polynesian Species of Peperomia. By T. G. Yuncker. Pp. 73. Bulletin 144: Polynesian Botanical Bibliography, 1773-1935. By E. D. Merrill. Pp. 194. Bulletin 145: Ethnology of Uvea (Wallis Island). By Edwin G. Burrows. Pp. $176+8$ plates. Bulletin 147 : The Genus Gouldia (Rubiaceæ). By F. Raymond Fosberg. Pp. $82+3$ plates. Bulletin 149: Report of the Director for 1936. By Peter H. Buck (Te Rangi Hiroa). Pp. 33. (Honolulu: Bernice P. Bishop Museum.) [248

Nutrition. Final Report of the Mixed Committee of the League of Nations on the Relation of Nutrition to Health, Agricultural and Economic Policy. (Official No.: A.13.1937.II.A.) Pp. 327. (Geneva: League of Nations; London: George Allen and Unwin, Ltd.) 7s. $6 d$.
[248

Proceedings of the California Academy of Science, Fourth Series. Vol. 23, No. 9: Mammals of Death Valley. By Joseph Grinnell Pp. 115-169. (San Francisco: California Academy of Sciences.)
[248 